\title{
Shared Leadership In IT Project Management: A Practice Survey
}

Chet Stagnaro, Freed Associates, USA

Chris Piotrowski, University of West Florida, USA

\begin{abstract}
In the management field today, shared leadership (SL) is considered a form of distributed leadership, conceptualized largely as working or functioning within a 'team' framework. Yet, there seems to be sparse research on the application of shared leadership principles in the IT field, particularly project management practices. To address this void in the literature, the current study was designed to determine the actual usage and assess the views of managerial-level practitioners toward SL. To that end, a 12-item Likert-type instrument was developed that reflected attitudes, intent, and actual usage. An E-mail response form was forwarded to a target sample of 250 IT project managers in the U.S. Of these, 102 responded with completed survey data. The independent variables in this study were gender, years in IT practice, and industry certification. These project managers expressed overwhelmingly positive attitudes and confirmed wide usage of SL in work-based projects. No significant differences, based on gender, years of experience, and certification were noted. Overall, these findings support the efficacy of the SL model and team-based leadership styles.
\end{abstract}

Keywords: Shared Leadership; Distributed Leadership; IT Project Management; Leadership Styles

\section{INTRODUCTION}

nformation technology (IT) project management specialists are required to both create and deliver optimal outcomes on any given project. At the same time, the project manager must orchestrate how the work output is organized, scheduled, and completed in accordance with the charter of the project. In practice, the IT project manager typically leads a group of experts across various knowledge domains such as servers, networks, databases, middleware, web services, security that support a business' various applications (e.g., financial applications and others). In this context, performance is largely based on a) leadership style and b) the integration of leadership behaviors in order to achieve desired outcomes.

Johnson, Boucher, Connors, and Robinson (2001) examined the relationship between leadership in project management and performance based on the project manager's ability to lead effectively, provide direction, and motivate co-workers. Results indicated that the project manager must integrate the interconnection with the key stakeholders (the project executive, the team, customers, and other stakeholders), select skills regarding group process (as a function of team building), and the establishment of leadership equilibrium (via sharing decisions - a key aspect of shared leadership). Indeed, these functions are all recognized key success factors in the everyday practice as a project manager.

From a practical standpoint, the shared leadership style seems to be a salient factor in the IT field since it is a management style and business strategy that coordinates the complexity of project functions. That is, "shared leadership" serves a complementary function in IT settings.

\section{Shared Leadership and IT}

There has been sparse research attention on aspects of shared leadership as a critical component to effective IT project management. Researchers have reported that critical success factors in project management often ignore 
the project manager's leadership style and level of competence which is in direct contrast to the study and application of leadership in the general management literature (Turner \& Müller, 2005). Thus, there is a need to examine how different styles of leadership relate to the IT project manager's effectiveness regarding the delivery of specific projects.

Leadership in project management, and particularly for complex technology such as IT projects, undoubtedly relies on teamwork. Researchers have observed that the role of the project manager (leader) can be considered that of "social architect" who develops a climate of active participation by involving project stakeholders at all levels in the planning, formation, and execution of projects (Norrie \& Walker, 2004; Thaimlain, 2004). In this context, researchers have discussed leadership as a process of social influence. For example, Bass (1990, p. 11) conceptualized leadership as a means of persuasion and power function, and defined leadership as, "the interaction between two or more members of a group that often involves structuring or restructuring of the situation and the perceptions and expectations of the members." Moreover, Bass stressed that leadership highlights the relationship of social influence wherein one group member modifies the motivation of fellow co-workers.

Project leadership can be viewed as those work activities that influence the motivation, knowledge, affect or practices of all team members. Therefore, a critical skill-set for a project manager is the ability to create activities that constructively influences the practices of team members. Extending this function, researchers have noted that the ability to motivate teams to reach decisions and to, thereby, assist teams in understanding and appreciating the project's objectives, goals, and products is another key attribute of the project manager (Avolio, Sivasubraminiam, Murray, Jung \& Garger, 2003; Norrie \& Walker, 2004). From a practical standpoint, "shared leadership" offers a style that recognizes this complexity in that there is a process of interdependence and mutual influence that team leaders and sub-teams have on the functionality and execution of projects. This is especially true for IT enterprisewide projects.

Finally, there is an historical precedence for shared leadership with regard to decision-making in IT projects. For such projects, Hallows (1998) recommends that the IT project manager facilitates fluid leadership. That is, on any issue, one team member (or team leader) may be more knowledgeable than the project manager, and so that person should be recognized to make the decision. Harrison (1992) provided another context of historical precedence for a collaborative, "employee-oriented" leadership style for project managers. Harrison asserted that this management style is quite efficacious. Furthermore, Dinsmore (1990) noted that participative decision-making meets the concerns and needs of the team and individual team members, and more importantly contributes to team unity.

\section{Purpose of the Study}

The aim of the current study is a) to assess attitudes toward the shared leadership style by project managers, b) to examine the extent of adopting 'shared leadership' behaviors as a management style in practice, and c) to investigate the influence of gender, certification status, and experience as factors in the implementation of shared leadership practices. To that end, survey data were obtained on a national sample of project managers.

\section{Theoretical Framework}

The work of Barker (2001), DeCarlo (2004), Fletcher and Kaufer (2003), Houghton, Neck, and Manz (2003), and Pearce and Conger (2003) describe shared leadership as a dynamic process with high levels of collaboration, peer influence and demonstration of leadership by a group as a whole. Sanders (2006) argued that shared leadership is a process of social influence in which individual members and the collective group lead one another to higher levels of achievement. Similarly, Wood and Fields (2007) describe shared leadership as the state or quality of mutual influence in which team members disperse leadership activities throughout a work group and collectively participate in the decision-making process. 


\section{Research Questions}

1. To what extent do Enterprise IT Project Managers use principles of "shared leadership"?

2. Are there significant differences in shared leadership use based on gender, professional certification, or years of experience?

\section{METHOD}

\section{Target Population and Sampling Strategy}

The objective of the research design was to sample IT project managers from different types of companies and IT settings to determine the use and implementation of SL in their work.

A sample size of 250 survey responses was collected in the SurveyMonkey® database. The sample size represented a 38\% response rate out of a possible 650 IT Project Manager population from California PMI chapters. Future studies should draw from a wider or national geographical population. Of the 250, 102 were usable responses or $40.8 \%$.

Overall, approximately $60 \%$ of the sample had between 5 to 15 years of experience in the project management field. Moreover, $43 \%$ of the project managers has managed or led between 3 and 9 very large enterprise-wide IT projects in their careers and nearly two-thirds hold PMI certification. Thus, the current sample of respondents was an experienced group of project managers with high professional status.

Table 1 Demographic and Professional Characteristics of Survey Respondents $(n=102)$

\begin{tabular}{|c|c|c|}
\hline Variable & $n$ & $\%$ \\
\hline \multicolumn{3}{|l|}{ Years of Experience as a Project Manager } \\
\hline $0-4$ years & 16 & 16.0 \\
\hline $5-10$ years & 31 & 30.4 \\
\hline $11-15$ years & 29 & 28.6 \\
\hline $16-19$ years & 13 & 12.5 \\
\hline $20+$ years & 13 & 12.5 \\
\hline \multicolumn{3}{|c|}{ Number of Enterprise Resource Planning Projects in Your Career } \\
\hline 2 or less & 27 & 26.8 \\
\hline $3-5$ & 24 & 23.2 \\
\hline $6-9$ & 20 & 19.6 \\
\hline $10+$ & 31 & 30.4 \\
\hline \multicolumn{3}{|l|}{ Certification } \\
\hline PMI Certified & 65 & 64.1 \\
\hline Not PMI Certified & 37 & 35.9 \\
\hline \multicolumn{3}{|l|}{ Age } \\
\hline $25-29$ years & 4 & 4.0 \\
\hline $30-39$ years & 24 & 23.5 \\
\hline $40-59$ years & 69 & 67.6 \\
\hline $60+$ years & 5 & 4.9 \\
\hline \multicolumn{3}{|l|}{ Gender } \\
\hline Male & 47 & 46 \\
\hline Female & 55 & 54 \\
\hline
\end{tabular}

\section{Instrumentation}

The research design included 2 measures: a Professional Status Form (PSF) to collect professional and demographical data, and the Project Leadership Scale to assess shared leadership practices. The Project Leadership 
Scale (PLS) was comprised of two parts. The first part included 7 items about the structure and function of shared leadership within the IT project team's roles and responsibilities as reported by the Project Manager; these items were developed and constructed by the first author based on his experience as an IT project manager. The second part included five items from the Perceived Leadership Behavior Scales (PLB) developed by House and Dessler (1974) to reflect leadership style. Thus, the total PLS had 12 items.

\section{Validity and Reliability}

The PLB construct is based on the path-goal theory of leadership (House \& Dessler, 1974). The PLB scale has been used in prior research studies and is cited in organizational behavior literature. The scale had an acceptable level of construct and criterion validity with regard to leadership behavior. The PLB measures three distinct aspects of leadership (House \& Dessler, 1974), including Participative leadership: a nondirective form of role clarifying behavior analogous to the more directive instrumental leadership. The PLB considers the degree to which leaders allow subordinates to influence decisions by asking subordinates for suggestions (also referred to as leadership participation). Only items from the Participation Leadership dimension were incorporated into the current scale.

\section{Procedure}

The PLS items were scored on a 5-point Likert-type scale (always $=5$, often $=4$, occasionally $=3$, seldom $=2$, and never $=1$ ). Survey Monkey ${ }^{\circledR}$ was used to create the electronic survey and to collect responses. The responses were administered across professional project management websites, and a survey link was included in survey participation email requests to all individuals in the sample.

\section{RESULTS}

The study examined the views and management style of IT project managers to determine the use and implementation of shared leadership in their practices. Also, differences in shared leadership style based on gender, status of professional certification, and experience level based on years of experience and prior enterprise-wide IT projects were investigated. Overall, these results indicated that, based on specific managerial behaviors that reflect a shared leadership style, IT project managers seemed to embrace a shared leadership orientation when working with colleagues and subordinates on major projects. However, data analyses revealed that there were no statistically significant differences for shared leadership in the current sample, based on sex, extent of experience or PMI certification status.

\section{Shared Leadership Scores Analyses}

Table 2 presents percentage scores for all 12 items on the Leadership Practices Survey based on the total of 102 respondents.

From a cursory review of the data presented in Table 2, it is apparent that the project managers hold favorable views on the use of shared leadership in their work. For example, $75 \%$ of the project managers shared decision-making authority with respect to work products and team lead decision-making authority was an important staffing consideration for over $75 \%$ of the project managers. This hiring consideration reflects an expectancy of shared decision-making on the part of the project managers. Moreover, only $16 \%$ of the project managers acknowledged that they seldom consult with the team on how to carry out project work.

Next, a sample $t$-test (one-tail) was performed to compare the mean of the shared leadership summary score for the entire sample and the "average" score of 24 to determine if the variance had any statistical significance; there was a statistically significant difference of 8.15 between the sample mean and the estimated population mean of score of $24(t(102)=15.69, p<.01)$. Thus, the Sample Shared Leadership mean $(M=32.15)$ was significantly higher than the average score of 24 indicating that as a whole, this sample of project managers rely on a shared leadership style in their work. 
Table 2 Survey Item Responses Based on Total Sample and by Gender

\begin{tabular}{|c|c|c|c|c|c|c|c|}
\hline Question & & $\begin{array}{c}\text { Always } \\
\%\end{array}$ & $\begin{array}{c}\text { Often } \\
\%\end{array}$ & $\begin{array}{c}\text { Occasionally } \\
\% \\
\end{array}$ & $\begin{array}{c}\text { Seldom } \\
\%\end{array}$ & $\begin{array}{c}\text { Never } \\
\%\end{array}$ & $\begin{array}{c}\text { Total } \\
\%\end{array}$ \\
\hline \multirow{3}{*}{$\begin{array}{l}\text { When faced with a specific problem, I consult with my } \\
\text { subordinates. }\end{array}$} & Total & 15.7 & 58.8 & 25.5 & 0 & 0 & 100 \\
\hline & Males & 15.4 & 61.5 & 23.1 & 0 & 0 & 100 \\
\hline & Females & 16.0 & 56.0 & 28.0 & 0 & 0 & 100 \\
\hline \multirow{3}{*}{$\begin{array}{l}\text { Before making a final decision, I give serious } \\
\text { consideration to what my subordinates have to say. }\end{array}$} & Total & 17.6 & 66.7 & 15.7 & 0 & 0 & 100 \\
\hline & Males & 7.7 & 76.9 & 15.4 & 0 & 0 & 100 \\
\hline & Females & 24.0 & 56.0 & 20.0 & 0 & 0 & 100 \\
\hline \multirow{3}{*}{$\begin{array}{l}\text { I ask subordinates for their suggestions concerning } \\
\text { how to carry out assignments or specific tasks. }\end{array}$} & Total & 9.8 & 45.1 & 31.4 & 13.7 & 0 & 100 \\
\hline & Males & 3.8 & 23.1 & 53.8 & 19.3 & 0 & 100 \\
\hline & Females & 4.0 & 24.0 & 56.0 & 16.0 & 0 & 100 \\
\hline \multirow{3}{*}{$\begin{array}{l}\text { Before taking final action on any specific aspect of the } \\
\text { project, I consult with my subordinates. }\end{array}$} & Total & 15.4 & 35.2 & 39.1 & 10.3 & 0 & 100 \\
\hline & Males & 15.4 & 42.3 & 34.6 & 7.7 & 0 & 100 \\
\hline & Females & 12.0 & 28.0 & 44.0 & 16.0 & 0 & 100 \\
\hline \multirow{3}{*}{$\begin{array}{l}\text { I ask subordinates for suggestions on what } \\
\text { assignments should be pursued or completed. }\end{array}$} & Total & 9.8 & 45.1 & 31.4 & 13.7 & & \\
\hline & Males & 3.8 & 61.5 & 34.7 & 0 & 0 & 100 \\
\hline & Females & 16.0 & 28.0 & 28.0 & 28.0 & 0 & 100 \\
\hline \multirow{3}{*}{$\begin{array}{l}\text { I staff my project with team leaders for specialized } \\
\text { groups such as a functional team or a technical team. }\end{array}$} & Total & 49.0 & 35.3 & 13.7 & 2.0 & 0 & 100 \\
\hline & Males & 57.7 & 30.8 & 11.5 & 0 & 0 & 100 \\
\hline & Females & 23.5 & 54.9 & 15.7 & 5.9 & 0 & 100 \\
\hline \multirow{3}{*}{$\begin{array}{l}\text { I generally allow team leads to provide input about the } \\
\text { project team organization and roles, but make the final } \\
\text { decisions. }\end{array}$} & Total & 23.5 & 54.9 & 15.7 & 5.9 & 0 & 100 \\
\hline & Males & 30.8 & 46.1 & 15.4 & 7.7 & 0 & 100 \\
\hline & Females & 16.0 & 64.0 & 16.0 & 4.0 & 0 & 100 \\
\hline \multirow{3}{*}{$\begin{array}{l}\text { Decision-making authority for team lead roles is an } \\
\text { important staffing consideration. }\end{array}$} & Total & 43.1 & 45.1 & 11.8 & 0 & 0 & 100 \\
\hline & Males & 50.0 & 42.3 & 7.7 & 0 & 0 & 100 \\
\hline & Females & 36.0 & 48.0 & 16.0 & 0 & 0 & 100 \\
\hline \multirow{3}{*}{$\begin{array}{l}\text { I typically provide coaching to the project team leads } \\
\text { so that they can be effective leaders. }\end{array}$} & Total & 25.5 & 51.0 & 19.6 & 3.9 & 0 & 100 \\
\hline & Males & 30.8 & 50.0 & 15.4 & 3.8 & 0 & 100 \\
\hline & Females & 20.0 & 52.0 & 24.0 & 4.0 & 0 & 100 \\
\hline \multirow{3}{*}{$\begin{array}{l}\text { I generally allow the project team leads to make the } \\
\text { decisions about how to design and execute the } \\
\text { project's work products and then hold them } \\
\text { accountable. }\end{array}$} & Total & 29.4 & 51.0 & 17.6 & 2.0 & 0 & 100 \\
\hline & Males & 30.8 & 50.0 & 15.4 & 3.8 & 0 & 100 \\
\hline & Females & 28.0 & 52.0 & 20.0 & 0 & 0 & 100 \\
\hline \multirow{3}{*}{$\begin{array}{l}\text { I provide guidelines to team leads for how the project's } \\
\text { work products should be performed and then they } \\
\text { make decisions within the guidelines. }\end{array}$} & Total & 23.5 & 51.0 & 23.5 & 2.0 & 0 & 100 \\
\hline & Males & 26.9 & 57.7 & 11.5 & 3.9 & 0 & 100 \\
\hline & Females & 20.0 & 44.0 & 36.0 & 0 & 0 & 100 \\
\hline \multirow{3}{*}{$\begin{array}{l}\text { I typically make most of the key decisions about how } \\
\text { the project's work products should be executed. }\end{array}$} & Total & 3.9 & 47.1 & 27.5 & 21.5 & 0 & 100 \\
\hline & Males & 7.7 & 53.8 & 15.4 & 23.1 & 0 & 100 \\
\hline & Females & 0 & 40.0 & 40.0 & 20.0 & 0 & 100 \\
\hline
\end{tabular}

\section{Group Comparisons: Shared Leadership Scores by Gender, Certification and Experience}

Gender

To explore the main effect of gender for shared leadership scores, an Analysis of Variance (ANOVA) model was examined. Results of this analysis suggested no significant differences by gender for shared leadership scores, $F(1,100)=1.275, p=.264$. Although the obtained means for males and females in this sample were marginally different, the difference was not statistically significant. Those differences are addressed later in this article.

\section{Certification Status}

To explore the main effect of certification on shared leadership scores, an Analysis of Variance (ANOVA) model was examined for those respondents who are certified in comparison to those not certified. Results of this analysis show no significant differences for shared leadership scores by certification, $F(1,100)=.085, p=.772$. While participants who were certified had somewhat higher shared leadership scores, than those who were not certified, the difference is not statistically significant. 


\section{Years of Experience}

To explore the main effect of years of experience for shared leadership scores, an Analysis of Variance (ANOVA) model was examined. For comparison purposes, only the extreme quadrants groupings on these variables were examined, leaving the 'middle' scores out. Thus, the least experienced quadrant of less than four years of experience versus the most experienced quadrant of greater than 16 years of experience were compared. In summary, results of this analysis suggest no statistically significant differences by years of experience for shared leadership scores, $F(1,100)=1.807, p=.195$. Thus, the least and most experienced project managers in this sample had similar shared leadership scores.

\section{Number of Projects}

To explore the main effect of number of projects as another measurement of the experience variable for shared leadership scores, an Analysis of Variance (ANOVA) model was examined. Similarly to the analysis of experience in number of years, the results of this analysis suggest no statistically significant differences by years of experience for shared leadership scores, $F(1,52)=1.521, p=.228$. Therefore, those with the least and most project experience had similar shared leadership scores.

\section{DISCUSSION AND CONCLUSIONS}

\section{General Findings}

The findings, based on the current sample, indicated that project managers had rather positive views toward shared leadership principles evidenced both in terms of sentiment and active leadership behaviors in their work. Based on aggregate data, $83 \%$ of the respondents indicated that they always/often hold positive attitudes as consideration of decision-sharing with team leads, consideration of decision-making as a staffing factor for them, and finally, coaching to improve their decision-making. This demonstrated Project Managers' high regard for sharing responsibility in planning projects, for staffing and training of subordinates to make decisions, and for sharing authority. Moreover, these same questions were associated in the belief and efficacy of a shared leadership team culture.

In terms of actual management style behaviors, a substantial majority (64\%) of these Project Managers indicated that in their daily activities, shared leadership techniques were used to accomplish project goals. In addition, $29 \%$ of the sample reported occasional or modest decision-making and only $7 \%$ reported seldom using these shared leadership practices. Thus, based on these findings, it appears that positive attitudes and sentiments toward a shared leadership perspective, on the part of IT project managers, facilitate the actual use of shared leadership principles in practice. Put another way, in the PM environment, shared leadership behaviors are largely a function of attitudes toward this specific type of management style.

Of the total sample, $78 \%$ of the respondents incorporated shared leadership strategies, i.e., encourage team members to contribute to the direction of the work and use shared leadership principles as a framework for selecting individual members to function as a team over the span of the project.

\section{Gender of Project Manager}

With respect to gender, overall there was not a statistically significant difference between male and female PMs on the implementation of SL principles. However, in performing an item-by-item analysis, there appeared to be a significant difference on several items, based on gender. This suggests that female project managers might be more equivocal in the use of shared leadership principles than their male counterparts. In fact, the current findings suggest that males tend to be somewhat more consultative and liberal, with regard to the use of shared decisionmaking, whereas females appeared to be somewhat more conservative in reserving more decision-making for themselves. Thus, prior research, in the context of the current analysis, shed some light on the possibility that the implementation of shared leadership principles may be partly a function of gender. For example, Thomas and Buckle-Henning (2007), in their study on the role of gender in PM practice, reported that the professional standard of best practices has a "masculine cognitive style," but found that both genders were equally skilled at balancing 
male and female cognitive styles. In general, these authors confirm that masculine and feminine cognitive styles are a reality and suggest that PMs need to be cognizant of their individual 'style' in order to attain optimal results on projects.

There is additional evidence in the literature that collaborative cognitive attributes, traditionally "feminine," could be skills acquired by men as well (Kelan, 2008). Based on these formulations, shared leadership, as a collaborative leadership model, may be conceptualized as a type of feminine cognitive style or an integrative mode of leadership. The current findings seem to offer an expository framework for why gender is not a predictive component in the use of shared leadership in the field of project management, but rather offers insight into shared leadership as embracing a gendered cognitive style that resides in both male and female managers. Other researchers have offered a conceptual framework on the role of feminine cognitive processes in conceptualizing the issue of people management in business (Foreman \& O’Brien, 2000; Klenke, 2003; Voelke, 2003).

\section{Findings in the Context of Prior Research}

In the general management field, several authors reported empirical data on the benefits of shared leadership as a framework with regard to sharing power and promoting organizational improvement and managerial collaboration. In a survey on the use of shared leadership across 22 academic libraries in the western U.S., Cawthorne (2010) investigated the extent of middle management participation in strategic decision-making. The survey participants responded to an online web-based survey to questions about their participation in decisionmaking and perception of their ability to influence decisions. Additional questions explored perceptions of management trust, personal commitment and accountability. The author found that shared leadership better informed senior managers since middle managers often had more information at their disposal. Moreover, the study found that shared information between senior and middle managers was important to effective shared leadership, and that there was disagreement among middle managers as to how effectively information flowed between senior and middle managers. Interestingly, Cawthorne reported that apparently less information flowed from the top down to middle management. Cawthorne concluded that shared leadership enhanced the ability of middle management to influence strategic decision-making. However, in contrast to the current research, his study found only moderate use of shared leadership among these organizations' managers whereas the current research found more extensive use of shared leadership among project managers.

Another exploratory study presented four cases of shared leadership use by top management in family-run organizations. As in the field of IT project management, shared leadership is also an under-researched leadership phenomenon in the field of family-run business studies (Cater \& Justis, 2010). Cater and Justis favored shared leadership as a viable alternative to the more traditional leadership model wherein a single leader is selected. Unlike the current research, this study relied upon qualitative research methods and obviously a much smaller sample population. Cater and Justis found that shared leadership posed problems for these kinds of 'family' organizations, i.e., confused reporting relationships due to overlap of leader roles, and slower-paced group decision-making. In this context, shared leadership (through group-decision-making) led to higher quality decision-making, even though it took longer for management to reach a decision. Furthermore, the study found that if the senior leaders refused to relinquish control over decision-making, then a shared leadership style could not progress in a constructive manner.

The lack of release of senior manager "control", i.e., decision-making, could be interpreted as a manifestation of a top-down, "command and control" style or vertical decision-making power dynamic that is stronger in these family-owned types of organizations. Hence, the adoption of shared leadership, although supported by prior case studies faces significant hurdles. Nonetheless, it is interesting to note that shared leadership is making management inroads into organizations with traditional top-down leadership styles.

Shared leadership does entail sharing decision-making authority (Greer \& Van Kleef, 2010). Greer and Van Kleef studied the effects of power dispersion and power equality within teams with respect to the team's ability to manage conflict resolution. They found that power equality facilitated conflict resolution, particularly in top management teams, "power structures that allow equality, such as shared leadership, may be most effective" (p. 1041). This finding may provide insight into why sharing decision-making power ultimately may lead to effective team dynamics for a project team, and that shared leadership supports a team structure of power-sharing. Similarly, Xue, Bradley, and Liang (2011), in a study of team collaboration, knowledge sharing and the effect of shared 
leadership on these team dynamics, found that team leader use of team member information and team member input into decisions led to higher levels of collaboration and cooperation. Overall, these studies would seem to support the current research findings with regard to providing more insight into why a shared leadership style among IT Project Managers is so popular and prevalent. Further study on the influence of shared leadership on team dynamics and conflict resolution in IT project teams may provide a conceptual understanding for its use in project management practice.

Heck and Hallinger (2010) studied the relationship of distributed (shared) leadership on organizational improvement in school performance. This study evaluated a longitudinal model on the effects of distributed leadership and change on school performance improvement. Heck and Hallinger found that changes in distributed school leadership have an indirect positive impact on school performance over time. Heck and Hallinger's study found that the effect of distributed leadership on organizational change is better understood over time rather than as a point-in-time phenomenon. This research has interesting implications for possible longitudinal investigations across IT programs, particularly projects as these introduce significant organizational change. Typically, projects are evaluated on a case study, point-in-time perspective. A longitudinal study of projects and the relationship of shared leadership may yield meaningful insight regarding the potential of shared leadership to effectively deliver successful organizational change.

\section{Project Management and the Current Findings}

The current findings support very positive views by project managers toward shared leadership. Furthermore, in the contemporary IT setting virtual teams benefit from shared (emergent) leadership style and a leadership culture that nourished team members' self-leadership and ongoing relational development (see Zigurs, 2002). In a study of shared leadership within a regional business development team, Cox (2009) found that shared or "collaborative" leadership, while being a multi-dimensional leadership phenomenon, was successful in that team members were able to achieve organizational goals through development of culture with strong interpersonal relations, shared decision-making power, and a high level of self-management among team members. This provides a concrete example of the shared leadership dynamic of peer influence or horizontal influence that was quite robust. Moreover, Cox provided an example of a self-leading team that operated to a degree of independence that most IT project teams could not sustain since typically IT project teams do rely on direction from sponsors and stakeholders in order to validate its work.

Wood and Fields (2007) studied shared leadership as a dispersal of decision-making power among all team members and examined the team dynamic of team members' mutual accountability. They found that shared decision-making contributed to team members being accountable for team results since they took an active role in leading the project team. The current research findings indicate that there is a strong preference for IT Project Managers to use a shared leadership style, thus supporting Wood and Fields's findings that shared leadership fits well with organizational team-based cultures such as IT departments and program management offices.

Burpitt and Bigoness (1997) evaluated the effect of leader empowerment of team members on innovation in architecture project teams. The study included various project teams across one U.S. architecture firm's national offices and involved 189 participants. These investigators found a positive relationship between empowered project teams and the ability to deliver innovative products by these teams. These results support the findings of the current research in that IT Project Managers very often consult with team members with regard to planning and use their input in decision-making. Moreover, IT project teams are often tasked by organizations to deliver innovative technology and business solutions. The current research shows that shared leadership does support team empowerments and thus may be a suitable leadership strategy that encourages team-level innovation.

Small (2007) investigated shared leadership in project teams using social network analysis and examined the effect of trust on shared leadership. Small found that the presence of trust has a direct relationship to the effective implementation of shared leadership within a project team. Finally, Sanders (2006) explored the individual and group dynamics of shared leadership among 520 participants working in new product teams. Shared leadership imparted a very positive influence on team effectiveness at both the individual and group levels of analysis. Sanders also found that vertical leadership might be less important to team effectiveness than previously thought, and that leadership development extended to team members might improve team effectiveness. Based on the current 
findings, most project managers do consider leadership and coaching factors to enhance team activities in their project management practice.

\section{Implications of the Current Findings}

The current findings have important implications regarding the degree and manner of implementation of shared leadership principles in contemporary business settings where Project Managers exercise a vital role. In fact, recent research on leadership has indicated that management style, to reach its optimal potential, needed to take into account the type of business context where managers functioned (see Hargis, Watt, \& Piotrowski, 2011). Apparently, based on views of respondents in the current study, IT fosters a working environment where the process of inter-group relations is as critical to business functions as economic parameters.

Thus, this study makes a contribution to both the shared leadership and IT project management literature by increasing awareness in these fields about this important leadership strategy and framework.

\section{CONCLUSIONS}

The current research concludes that shared leadership is a prevalent leadership style among IT Project Managers regardless of gender, credentialing and length of experience in the field. In regard to efficacy, shared leadership principles appear to foster empowerment to all employees and enhance inter-group motivation and cooperation in critical-level employees and subordinates. Leadership studies support the notion that overall creative potential is maximized when both subordinates and managers both contribute to the process and outcome of projects (Kouzes \& Posner, 2002). In this regard, team cohesiveness fosters team self-esteem, and mutual trust and respect (Lin, Baruch, \& Shih, 2012; Nelson \& Quick, 2003, pp. 299-302). Furthermore, the shared leadership model appears to mitigate isolation and risk; counter-productive elements in the hi-tech project management environment.

\section{AUTHOR INFORMATION}

Chet Stagnaro is a practicing IT Program Manager with nearly 30 years career experience in business and IT project and program management. He has a Master's degree in business and another Master's in Computer Information Systems, and recently completed his Doctoral studies in Management with the Institute for Advanced Studies, Colorado Technical University. Chet's academic interests are in the areas of applied leadership and team performance in the field of IT program and project management. He is currently engaged in IT consulting and program management in healthcare, and is currently employed with a healthcare management consulting firm in the San Francisco Bay Area. E-mail: cstagnaro@earthlink.net (Corresponding author)

Chris Piotrowski has been a research consultant for the past 30 years, serving the professional community as well as faculty at the University of West Florida. Chris has a multidisciplinary orientation, based on graduate education and research practice, from training in the social sciences, management, psychometrics, and bibliometrics perspectives. Chris has authored over 200 peer-reviewed articles and 15 book chapters. In addition, his research has been cited in leading journals and books. As a professional service, Chris serves as a journal reviewer for over 20 scholarly journals. E-mail: cpiotrowski@uwf.edu or Piotrowskichris@ hotmail.com

\section{REFERENCES}

1. Avolio, B. J., Sivasubraminiam, N., Murry, W. D., Jung D., \& Garger, J.W. (2003). Assessing shared leadership: Development and preliminary validation of a team multifactor leadership questionnaire. In C.L. Pearce \& J.A. Conger (Eds.), Shared leadership: Reframing the hows and whys of leadership (pp. 143- 172). Thousand Oaks, CA: Sage.

2. $\quad$ Barker, R. (2001). The nature of leadership. Human Relations, 54(4), 469-494.

3. Bass, B. (1990). Bass \& Stodgill's handbook of leadership: Theory, research, and managerial applications. New York, NY: Free Press.

4. Benson, A., \& Blackman, D. (2010, April). To distribute leadership or not? A lesson from the islands. Tourism Management, 1-9. 
5. Burpitt, W., \& Bigoness, W. (1997). Leadership and innovation among teams: The impact of empowerment. Small Group Research, 28(3), 414-423.

6. Cater, J., \& Justis, R. (2010). The development and implementation of shared leadership in multigenerational family firms. Management Research Review, 33(6), 563-588.

7. Cawthorne, J. (2010). Leading from the middle of the organization: An examination of shared leadership in academic libraries. The Journal of Academic Librarianship, 36(2), 151-157.

8. Cox, J. D. (2009). Leadership without a leader: An exploratory study of collaborative leadership. Dissertation Abstracts, Ann Arbor, MI: ProQuest UMI Dissertation Services, (UMI No. 305159331).

9. DeCarlo, D. (2004). Extreme project management: Using leadership, principles, and tools to deliver value in the face of volatility. San Francisco, CA: Jossey-Bass.

10. Dinsmore, P. (1990). Human factors in project management. New York, NY: American Management Association.

11. Fletcher, J., \& Kaufer K. (2003). Shared leadership: Paradox and possibility. In C. Pearce \& J. Conger (Eds.), Shared leadership: Reframing the hows and whys of leadership (pp. 21-42). Thousand Oaks, CA: Sage.

12. Foreman, J., \& O'Brien, F. (2000). Gender restructuring and management in the UK: Project management and human resources management influx. Management Research News, 23, 9-11.

13. Greer, L., \& Van Kleef, A. (2010). Equality versus differentiation: The effects of power dispersion on group interaction. Journal of Applied Psychology, 95(6), 1032-1044.

14. Hallows, J. (1998). Information systems projects: How to deliver function and value in information technology projects. New York, NY: American Management Association.

15. Hargis, M.B., Watt, J.D., \& Piotrowski, C. (2011). Developing leaders: Examining the role of transactional and transformational leadership across business contexts. Organization Development Journal, 29(3), 51-66.

16. Harrison, F. L. (1992). Advanced project management: A structured approach (3 ${ }^{\text {rd }}$ ed.). New York, NY: Halsted Press.

17. Heck R., \& Hallinger, P. (2010). Testing a longitudinal model of distributed leadership effects on school improvement. The Leadership Quarterly, 21, 867-885.

18. Houghton, J., Neck, C., \& Manz, C. (2003). Self-leadership and super-leadership: The heart and art of creating shared leadership in teams. In C. Pearce \& J. Conger (Eds.), Shared leadership: Reframing the hows and whys of leadership (pp. 123-135). Thousand Oaks, CA: Sage.

19. House, R., \& Dessler, G. (1974). The path-goal theory of leadership: Some post hoc and a priori tests. In J. G. Hunt \& L. L. Larson (Eds.), Contingency approaches to leadership: A symposium held at Southern Illinois University (pp. 29-55). Carbondale, IL: Southern Illinois University Press.

20. Johnson, J., Boucher, K., Connors, K., \& Robinson, J. (2001). Collaborating on project success. Retrieved December 21, 2007 from http://www.softwaremag.com/archive/2001feb/CollaborativeMgt.html

21. Kelan, E. K. (2008). The discursive construction of gender in contemporary management literature. Journal of Business Ethics, 81(2), 427-445.

22. Kouzes, J.M., \& Posner, B. (2002). The leadership challenge ( ${ }^{\text {rd }}$ ed.). San Francisco, CA: Jossey-Bass.

23. Lin, C., Baruch, Y., \& Shih, W. (2012). Corporate social responsibility and team performance: The mediating role of team efficacy and team self-esteem. Journal of Business Ethics, 108, 167-180.

24. Nelson, D.L., \& Quick, J.C. (2003). Organizational behavior (4th ed.). Mason, OH: Thomson.

25. Norrie, J., \& Walker, D. (2004). A balanced scorecard approach to project management leadership. The Project Management Journal, 35(4), 49-58.

26. Pearce, C., \& Conger, J. (2003). All those years ago: The historical underpinnings of shared leadership. In C. Pearce \& J. Conger (Eds.), Shared leadership: Reframing the hows and whys of leadership (pp.1-13). Thousand Oaks, CA: Sage.

27. Sanders, T. (2006). Collectivity and influence: The nature of shared leadership and its relationship with team learning orientation, vertical leadership and TEA. Dissertation Abstracts, Ann Arbor, MI: ProQuest UMI Dissertation Services, (UMI No. 3237041).

28. Small, E. E. (2007). Shared leadership: A social network analysis. The University of Tennessee. ProQuest Dissertations and Theses, n/a. Retrieved from http://search.proquest.com/docview/304830042 ?accountid=26967. (304830042)

29. Thaimlain, H. J. (2004). Team leadership: Effectiveness in technology-based project environments. Project Management Journal, 35(4), 37-48. 
30. Thomas, J., \& Buckle-Henning, P. (2007). Dancing in the white spaces: Exploring gender assumptions in successful project managers' discourse about their work. International Journal of Project Management, 25, 552-559.

31. Turner, R., \& Müller, R. (2005). The project manager's leadership style as a success factor on projects: A literature review. The Project Management Journal, 36(2), 51-63.

32. Voelck, J. (2003). Directive and connective: Gender-based differences in the management styles of academic library managers. Johns Hopkins University Press Portal: Libraries and the Academy, 3(3), 393418.

33. Wood, M., \& Fields, D. (2007). Exploring the impact of shared leadership on management team member job outcomes. Baltic Journal of Management, 2(3), 251-272.

34. Xue, Y., Bradley, J., \& Liang, H. (2011). Team climate, empowering leadership and knowledge sharing. Journal of Knowledge Management, 15(2), 299-312.

35. Zigurs, I. (2002). Leadership in virtual teams: Oxymoron or opportunity? Organizational Dynamics, 31(4), 339-351. 
NOTES 